\title{
ASSESSMENT OF THE OSMO-CONVECTIVE DEHYDRATION ON THE QUALITY ATTRIBUTES AND CENTESIMAL COMPOSITION OF YACON (Smallanthus sonchifolius)
}

\author{
CAMILA AUGUSTO PERUSSELLO * \\ VIVIANA COCCO MARIANI ** \\ MARIA LÚCIA MASSON*** \\ FERNANDA DE CASTILHOS****
}

\begin{abstract}
This work has studied the application of the osmo-convective dehydration on yacon roots, regarding its composition and quality attributes. Slices of yacon were submitted to osmotic treatment with sucralose solution followed by convective dry. The experiments followed a complete $2^{3}$ factorial design to assessthe effect of three variables of the process (temperature, stirring rate of the osmotic solution and drying temperature) over four quality attributes (moisture content, color, luminosity and soluble solid content). The application of the osmotic treatment before convective drying provided quality gains to the dried product, such as low browning and shrinkage rates, and reduction of the structural damages towards angular distortions and fissures, in comparison to the samples dried directly on the tray dryer. The effect of osmotic treatment over the centesimal composition of yacon have resulted on absorption of sucralose and water loss without a significance compromise of its nutritional attributes. The obtained product presented different contents of moisture, but similar levels of darkening and color alteration at diverse experimental conditions.
\end{abstract}

* PhD Student, Program of Food Engineering, Department of Chemical Engineering, Federal University of Paraná, Curitiba, PR, Brazil (e-mail: camila_ea@yahoo.com.br).

** PhD in Mechanical Engineering, Professor, the Department of Mechanical Engineering, Pontifical Catholic University of Paraná, Curitiba, PR, Brazil (e-mail: viviana.mariani@pucpr.br).

*** PhD in Chemical Engineering, Professor, the Department of Chemical Engineering, Federal University of Paraná, Curitiba, PR,Brazil (e-mail: masson@ufpr.br).

**** PhD in Chemical Engineering, Professor, the Department of Chemical Engineering, Federal University of Santa Maria, Santa Maria, RS, Brazil (e-mail: fer.castilhos@gmail.com). 


\section{INTRODUCTION}

Yacon is a root with approximately $90 \%$ of moisture content (w.b.) that is original from the Andes region, and is produced in many parts of the world, such as Brazil.Yacon can be consumed in the in natura or dried form and can also be added as a dried powder in juices, yogurts and bakery products. The use of yacon is related to its prebiotic power, due to the fructan presence, such as the fructooligosaccharides (FOS) and inulins (PEDRESCHI et al., 2003). Besides the bifidogenic activity, which is responsible for the prebiotic property of yacon, FOS are also related to antioxidant activities, to the reduction on the glucose and triglycerides levels in the blood, to blood pressure normalization and to the diabetic metabolism improvement (TAKENAKA et al., 2003; YAN et al., 1999; HARTEMINK, VANLAERE \& ROMBOUTS, 1997).

The yacon root has a very high water activity, thus it is necessary to process it in order to preserve it from enzymatic and microbiologic degradation. Drying is one of the most used operations as a method of conservation in the food industry. Dried products have limited deterioration rates, are easily transported and stored because of the reduced volume, and do not require refrigeration, representing energy economy. Considering that important alterations on flavor, color and aroma can take place during the process and that drying operations correspond up to $15 \%$ of the food industry energy demand (CHUA et al., 2001), it is mandatory to study the food characteristics and the drying conditions in order to obtain the desired final product with the lowest energetic usage possible. The use of relatively high temperatures during the convective drying, in order to achieve high mass transfer rates, can account for damages such as enzymatic browning and shrinkage. An alternative to minimize the product thermo degradation is to reduce its initial water content by an osmotic dehydration process. In the osmotic treatment, fruits and vegetables are immersed in a saturated solution of osmotic agent at low temperatures, allowing partial concentration of the cellular material (TORREGGIANI, 1993; LENART, 1996). Some of the advantages provided by this process include improvement of color, flavor and texture, as well as the enhancement of pigment and nutrients stability during storage (LAZARIDES, KATSANIDIS \& NICKOLAIDIS, 1995; RAOULT-WACK et al., 1994). The removal of water during the osmotic treatment also leads to a lower energy requirement during convective drying process.

A high number of studies have been carried out in order to analyze the convective drying process preceded by the osmotic treatment (VIEIRA, PEREIRA and HUBINGER, 2012; VEGAGÁLVEZ et al., 2011; PATTANAPA et al., 2010; MUNDADA,SINGH \& MASKE, 2010; IBITWAR et al., 2008; PEKOSLAWSKA and LENART, 2009; among others), however only a few of them is regarding to yacon. In the study of Masson, Moura and Yamamoto (2004), yacon was treated in a sorbitol osmotic solution $(50 \% \mathrm{w} / \mathrm{w})$ at $30^{\circ} \mathrm{C}$ with stirring rate of $110 \mathrm{rpm}$ for 3 hours and then dried in a convective dryer at $50^{\circ} \mathrm{C}$ during 6 hours. Another sample of in natura yacon was dried directly in the convective dryer at $50^{\circ} \mathrm{C}$ for 9 hours. The results showed that the osmotic treatment decreased moisture content and promoted color preservation. Maldonado et al. (2008) osmo-dried yacon in a sucrose solution $(40 \% \mathrm{w} / \mathrm{w})$ at $25^{\circ} \mathrm{C}$ and agitation rate of $105 \mathrm{rpm}$ until the water activity of 0.97 . Considering that the average solid uptake and water loss obtained were $9.5 \mathrm{~g} / 100 \mathrm{~g}$ of fresh material and $68.8 \mathrm{~g} / 100 \mathrm{~g}$ of fresh material, respectively, the authors concluded that the osmotic dehydration is a valid conservation pretreatment to the yacon roots.

The main objective of this work was to investigate the influence of the osmotic treatment conditions on the quality attributes and centesimal composition of the air-dried yacon. In order to achieve this goal, slices of in natura yacon were submitted to an osmotic treatment using a sucralose solution, followed by a convective drying process. The yacon centesimal composition was determined before and after the osmotic dehydration, and a statistical analysis of the osmo-dried product quality attributes (color, luminosity, moisture content and soluble solids content) was performed. Therefore, the main contribution of this work is the investigation of the effects of the osmo-convective drying of yacon not only in the moisture loss and solids uptake, but also on several quality attributes and 
centesimal composition, allowing a more complete analysis of this process.

\section{MATERIAL AND METHODS}

\subsection{MATERIAL}

Yacon roots (Smallanthus sonchifolius) purchased at a local market in the city of Curitiba (Paraná-Brazil) and kept under refrigeration, were previously peeled and shaped into radial slices of $2 \mathrm{~mm}$ thickness. The yacon roots were selected visually based on their similar degree of ripeness (same skin color), apparent quality (flawlessness), similar size, peel uniformity, and absence of fissures.

The osmotic agent used was sucralose (brand Linea Ltda.), a sugar cane derivate with lowered calorie value. Sucralose has high temperature and $\mathrm{pH}$ stability and high water solubility (NACHTIGALL and ZAMBIAZI, 2006; JENNER and SMITHSON, 1989).

\subsection{METHODS}

\subsubsection{Centesimal composition}

The centesimal composition for the yaconin natura and after the osmotic dehydration was obtained through standardized techniques from Association of Official Analytical Chemists (AOAC), which can be found in Matissek, Schnepel and Steiner (1998). The protein content was analyzed by the Kjedahl digestion method, the lipid evaluation was performed by the Soxhlet continuous extraction and the ashes content was analyzed by the sample incineration in a muffle furnace, at $550^{\circ} \mathrm{C}$. The moisture content followed the gravimetric analysis, using a vacuum oven at $105^{\circ} \mathrm{C}$. The total carbohydrate content was calculated by difference.

\subsubsection{Osmotic dehydration and convective drying}

The osmotic dehydration was carried out in a thermostatic bath (Quimis, model Dubnoff Q-226M2) with temperature and stirring control using a sucralose solution. The convective drying was conducted in a tray dryer with forced ventilation (Fabbe, model 170). The experiments were carried out in triplicate according to the study of Masson, Moura and Yamamoto (2004).

Four beakers containing $140.0 \pm 0.5 \mathrm{~g}$ of $20 \%(\mathrm{w} / \mathrm{w})$ concentration sucralose solution and $28.6 \pm 1.2 \mathrm{~g}$ of yacon slices were conditioned in the thermostatic bath. The proportion between yacon and solution was $1: 5(\mathrm{w} / \mathrm{w})$. Temperature and stirring rate were set according to the experimental design, being $30^{\circ} \mathrm{C}$ and $50^{\circ} \mathrm{C}$ to the osmotic solution temperature, $0 \mathrm{~cm} / \mathrm{s}$ and $4 \mathrm{~cm} / \mathrm{s}$ to the solution stirring rate, and $60^{\circ} \mathrm{C}$ and $80^{\circ} \mathrm{C}$ to the drying temperature. The osmotic dehydration lasted 2 hours. The process time for the osmotic dehydration was obtained in preliminary tests, which have showed that above 2 hours of process, the water loss ceases, giving place only to the solid gain, being also detrimental to the color and texture of yacon. Each beaker was removed from the thermostatic bath at a defined time interval (30 $\mathrm{min}, 60 \mathrm{~min}, 90 \mathrm{~min}$ and $120 \mathrm{~min}$ ), the slices were wiped with absorbent paper and weighted with an analytical scale.

After the osmotic treatment, the slices were dried for 3 hours in a tray dryer using temperatures of $60^{\circ} \mathrm{C}$ and $80^{\circ} \mathrm{C}$. This process time, determined in preliminary tests, is the sufficient time to reach the stabilization of the yacon slices' weight in any experimental condition used in this work. As the convective dryer does not present a relative humidity $(\mathrm{RH})$ control, this parameter was measured with a multimeter brand Testo, model 445 , resulting in the value of $20.95 \pm 2.28 \%$. Another sample of yacon, without the osmotic treatment, was also submitted to the convective drying process, with the purpose to compare the overall product quality with and without the osmotic treatment. 
The mass variation, or weight loss, of the slices during the osmotic treatment, $\Delta M(\mathrm{~g} / \mathrm{g})$, was calculated by Equation 1:

$$
\Delta M=\frac{\left(M_{i+1}-M_{i}\right)}{M_{i}},
$$

Being:

$M_{i}$ the mass in a time $i(\mathrm{~g})$ and $M_{i+1}$ the mass at the next time interval, during the osmotic treatment.

The weight loss is composed of two parts: the solid components transfer and the water transfer, which were also calculated. The yacon solids mass, $S_{i}(\mathrm{~g})$, was obtained by Equation 2 :

$$
S_{i}=M_{i}-\frac{X_{i} \times M_{i}}{100}
$$

Being:

$S_{i}$ the yacon solids mass in a time $i(\mathrm{~g})$ and $X_{i}$ the moisture content (w.b.) in a time $i(\%)$, obtained by gravimetric analysis.

The yacon water mass, $W_{i}(\mathrm{~g})$, was calculated by Equation 3 :

$$
W_{i}=\frac{X_{i} \times M_{i}}{100} .
$$

Hence, the mass variation of yacon during the whole osmotic dehydration, $\Delta M(\mathrm{~g} / \mathrm{g})$, can also be calculated by Equation 4:

$$
\Delta M=\frac{M_{i}-M_{0}}{M_{0}}=\frac{S_{i}-S_{0}+W_{i}-W_{0}}{M_{0}}
$$

Being:

$M_{0}(\mathrm{~g}), S_{0}(\mathrm{~g})$ and $W_{o}(\mathrm{~g})$ the total mass, solids mass and water mass, respectively, for the in natura yacon.

The mass of the yacon slices during the convective drying, $M c(\mathrm{~g} / \mathrm{g})$, was normalized so that the curves for all tests begin at the same point. Hence, Mc was calculated by Equation 5 :

$$
M c=100 \times \frac{M c_{i}}{M c_{0}}
$$

Being:

$M c_{i}$ the mass in a time $i(\mathrm{~g})$ and $M c_{0}$ the mass at the beginning of the test, in the convective drying.

\subsubsection{Experimental design}

The experiments followed a full $2^{3}$ factorial design, where 2 is related to the number of levels to be studied and 3 is related to the number of variables being evaluated, which are the osmotic solution temperature, the osmotic solution stirring rate and the drying temperature. The experimental design is sketched in Table 1. 
TABLE 1 - EXPERIMENTAL DESIGN SKETCH

\begin{tabular}{c|c|c|c|c}
\hline \multirow{2}{*}{ Variable } & \multirow{2}{*}{ Variable code } & \multicolumn{3}{|c}{ Level } \\
\cline { 3 - 5 } & & -1 & 0 & 1 \\
\hline Solution temperature $\left({ }^{\circ} \mathrm{C}\right)$ & $\mathrm{x} 1$ & 30 & 40 & 50 \\
\hline Solution stirring rate $\left.\left(\mathrm{cm}^{-1}\right)^{-1}\right)$ & $\mathrm{x} 2$ & 0 & 2 & 4 \\
\hline Drying temperature $\left({ }^{\circ} \mathrm{C}\right)$ & $\mathrm{x} 3$ & 60 & 70 & 80 \\
\hline
\end{tabular}

The answers obtained for each experiment were: $y 1=$ moisture content w.b. (\%), $\mathrm{y} 2=$ darkening degree (dimensionless), $\mathrm{y} 3=$ color change $(\mathrm{rad})$ and $\mathrm{y} 4=$ soluble solids concentration ( ${ }^{\circ}$ Brix).

\subsubsection{Determination of yacon quality attributes}

During the processes of osmotic treatment and convective drying, the attributes moisture content, color and luminosity were measured at intervals of 30 minutes. The soluble solids concentration was measured before and after the osmotic dehydration using a refractometer (PZO Warszawa, model RL3), according to Instituto Adolfo Lutz (1985). This analysis was carried out with the juice extracted from the yacon slices, obtained by mechanical pressing. The structure of the product was also evaluated along the processes, visually, regarding to shrinkage and presence of fissures and angular distortions.

The moisture content was determined by the gravimetric method, as quoted in section 2.2.1. Luminosity and color were measured with a colorimeter (Hunter Lab Mini Scan, model XE Plus), according to the Commision Internationale L'Eclarirage System, which establishes the uniform coordinates $L^{*} a^{*} b^{*}$ on the color three-dimensional space (LAWLESS and HEYMANN, 2010). Luminosity, represented by the $L^{*}$ coordinate, varies from 0 (darkness) to 100 (brightness). The differences on luminosity, which represent the darkening degree of the factorial design, $y 2$, were calculated by Equation 6:

$$
\Delta L=L_{0}^{*}-L_{f^{\prime}}^{*}
$$

Being:

$L^{*}{ }_{0}$ the luminosity of the in natura slices and $L^{*}{ }_{f}$ the luminosity of the dried slices.

The chroma information is represented by the $a^{*}$ and $b^{*}$ coordinates: $a^{*}$ corresponds to the axis that ranges from green to red, assuming values from -60 to +60 , and $b^{*}$ represents the axis that varies from blue to yellow, assuming values from -60 to +60 . The tone angle, $h$, a property related to the spectral color wave length, was used to represent the difference on the product color, $y 3$, as it follows:

$$
h=\tan ^{-1}\left(\frac{b^{*}}{a^{*}}\right)
$$




\subsubsection{Statistical Analysis}

The statistical analysis was performed using the software Statistica (StatSoft ${ }^{\circledR}$ ) version 7. Differences between the means were analyzed using ANOVA. Tukey's test was used to identify differences at the 95\% significance level (KEPPEL and WICKENS, 2004).

\section{RESULTS AND DISCUSSIONS}

\subsection{CENTESIMAL COMPOSITION OF THE YACON IN NATURA AND OSMOTIC DEHYDRATED}

The results presented in Table 2 show that carbohydrates are the main component on the in natura yacon solid content. These results are in accordance with literature (HERMANN and FREIRE, 1998). During the osmotic dehydration, there were water loss and sweetener uptake, with statistically similar results for all experimental conditions. The significant differences regarding to water loss and sugar uptake can be seen only between in natura and osmo-treated yacon, in any process condition. The percentage losses of proteins, fats and minerals were $16.98 \pm 9.11 \%, 14.74 \pm 11.15 \%$ and $23.39 \pm 20.80 \%$, which are similar to the results found by Araújo (2009) for the osmotic dehydration of red-iamb (Syzygium malaccensis) in sucrose solution.

\section{TABLE 2 - CENTESIMAL COMPOSITION OF YACON IN NATURA AND SUBMITTED TO DIFFERENT PROCESS CONDITIONS}

\begin{tabular}{c|c|c|c|c|c|c}
\hline \multirow{2}{*}{ Sample } & \multicolumn{2}{|c|}{ Moisturecontent } & Proteins & Fats & Minerals & $\begin{array}{c}\text { Total } \\
\text { Carbohydrates }\end{array}$ \\
\cline { 2 - 6 } & Wetbasis (\%) & $\begin{array}{c}\text { Dry basis } \\
(\mathbf{g} / g \text { yacon) }\end{array}$ & $(\%)$ & $(\%)$ & $(\%)$ & $(\%)$ \\
\hline in natura & $93.61 \pm 0.06^{\mathrm{a}}$ & $14.64 \pm 0.15^{\mathrm{a}}$ & $0.53 \pm 0.06^{\mathrm{a}}$ & $0.39 \pm 0.03^{\mathrm{a}}$ & $0.31 \pm 0.05^{\mathrm{a}}$ & $5.09 \pm 0.03^{\mathrm{a}}$ \\
\hline $30^{\circ} \mathrm{C}$ and $0 \mathrm{~cm} / \mathrm{s}$ & $88.80 \pm 0.38^{\mathrm{b}}$ & $7.93 \pm 0.30^{\mathrm{b}}$ & $0.43 \pm 0.04^{\mathrm{ab}}$ & $0.31 \pm 0.08^{\mathrm{a}}$ & $0.28 \pm 0.03^{\mathrm{a}}$ & $10.32 \pm 0.47^{\mathrm{b}}$ \\
\hline $30^{\circ} \mathrm{C}$ and $4 \mathrm{~cm} / \mathrm{s}$ & $88.21 \pm 0.58^{\mathrm{b}}$ & $7.50 \pm 0.43^{\mathrm{b}}$ & $0.40 \pm 0.03^{\mathrm{b}}$ & $0.29 \pm 0.06^{\mathrm{a}}$ & $0.16 \pm 0.01^{\mathrm{b}}$ & $10.93 \pm 0.61^{\mathrm{b}}$ \\
\hline $50^{\circ} \mathrm{C}$ and $0 \mathrm{~cm} / \mathrm{s}$ & $88.67 \pm 0.15^{\mathrm{b}}$ & $7.83 \pm 0.12^{\mathrm{b}}$ & $0.42 \pm 0.04^{\mathrm{bc}}$ & $0.34 \pm 0.16^{\mathrm{a}}$ & $0.21 \pm 0.07^{\mathrm{ab}}$ & $10.35 \pm 0.24^{\mathrm{b}}$ \\
\hline $50^{\circ} \mathrm{C}$ and $4 \mathrm{~cm} / \mathrm{s}$ & $88.40 \pm 0.10^{\mathrm{b}}$ & $7.62 \pm 0.07^{\mathrm{b}}$ & $0.51 \pm 0.01^{\mathrm{ac}}$ & $0.39 \pm 0.01^{\mathrm{a}}$ & $0.30 \pm 0.01^{\mathrm{a}}$ & $10.41 \pm 0.10^{\mathrm{b}}$ \\
\hline
\end{tabular}

a-c Means within the same column with different letters are significantly different $(p \leq 0.05)$.

\subsection{OSMOTIC DEHYDRATION}

Figure 1 presents the mass variation of the yacon slices during the osmotic treatment. The processes using $50^{\circ} \mathrm{C}$ provided a higher mass loss in comparison with the ones using $30^{\circ} \mathrm{C}$. In fact, the in natura slices with a mass of $28.90 \pm 0.96 \mathrm{~g}$ reached the end of the osmotic treatment with $28.73 \pm 1.14 \mathrm{~g}$ using $30^{\circ} \mathrm{C}$ and $14.28 \pm 2.91 \mathrm{~g}$ using $50^{\circ} \mathrm{C}$. Similar results, regarding to the positive effect of temperature on the weight loss, were reported by several studies (OZDEMIR et al., 2008; ISPIR and TOGRUL, 2009; LOMBARD et al., 2008; ANTONIO et al., 2008). This effect can be explained by the heat action on the cellular tissue softening, leading to an increase on its permeability, and therefore facilitating the transport of the water molecules and soluble solids from the product to the osmotic solution. Moreover, as reported by Singh, Kumar and Gupta (2007), the decrease of a concentrated solution viscosity, due to the temperature effect, leads to higher water diffusion rates. 


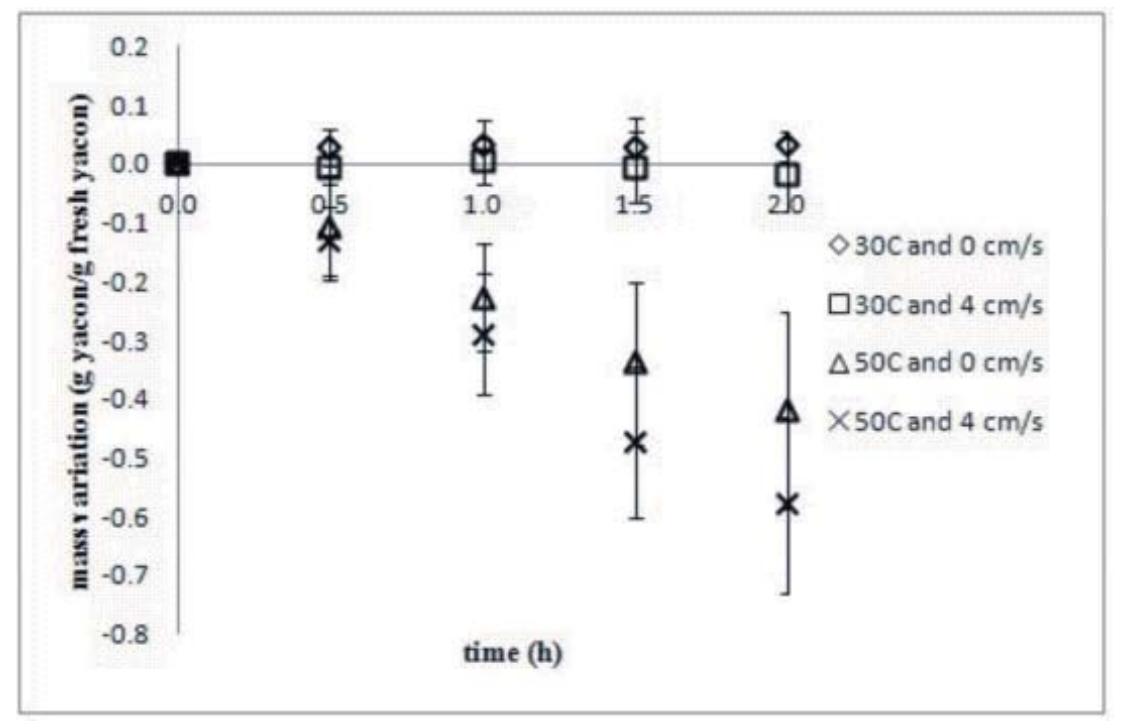

FIGURE 1 - MASS VARIATION OF THE YACON SLICES DURING THE OSMOTIC TREATMENT

Table 3 shows the variation of the mass, water content and solid fraction of yacon during the osmotic treatment. Yacon lost weight at all conditions, except for $30^{\circ} \mathrm{C}$ and $0 \mathrm{~cm} / \mathrm{s}$, being the mass loss, $\Delta M$, significantly higher for the processes at $50^{\circ} \mathrm{C}$. Actually, all the mass transfer processes (water and solids) were favored by the temperature increase, which is confirmed by the statistical analysis, as can be seen in Table 3. Although the temperature effect is more pronounced than the stirring effect, it is worthwhile to state that the stirring rate of the osmotic solution also influenced the results obtained in this study. The transfer velocity of a component in a medium is the result of the contribution of diffusive motion (due to the gradient of concentrations) and convective motion (due to the global movement of the fluid). Thus, stirring increases the transfer rate of solids and water from yacon to the osmotic solution. In the processes without stirring, as the transfer processes occur only as a result of the concentration gradients, they assume lower velocities. Using $30^{\circ} \mathrm{C}$ without stirring, the product gained water and lost solids, which is an absolutely undesirable result, while using stirring, there were loss of water and solids. For the osmotic solution at $50^{\circ} \mathrm{C}$, the stirring rate increased both water and solid losses.

TABLE 3 - VARIATION OF THE MASS $(\Delta M)$, WATER CONTENT ( $\triangle M$ ) AND SOLID CONTENT $(\Delta S)$ OF YACON IN DIFFERENT PROCESS CONDITIONS

\begin{tabular}{c|c|c|c}
\hline Process conditions & $\Delta \boldsymbol{M}(\mathbf{g})$ & $\Delta \boldsymbol{W} \mathbf{( g )}$ & $\Delta \boldsymbol{S} \mathbf{( g )}$ \\
\hline $30^{\circ} \mathrm{C}$ and $0 \mathrm{~cm} / \mathrm{s}$ & $0.87 \pm 0.76^{\mathrm{a}}$ & $0.91 \pm 0.94^{\mathrm{a}}$ & $-0.04 \pm 0.29^{\mathrm{a}}$ \\
\hline $30^{\circ} \mathrm{C}$ and $4 \mathrm{~cm} / \mathrm{s}$ & $-0.87 \pm 1.91^{\mathrm{a}}$ & $-0.67 \pm 1.72^{\mathrm{a}}$ & $-0.20 \pm 0.33^{\mathrm{a}}$ \\
\hline $50^{\circ} \mathrm{C}$ and $0 \mathrm{~cm} / \mathrm{s}$ & $-12.27 \pm 5.54^{\mathrm{b}}$ & $-11.27 \pm 1.72^{\mathrm{b}}$ & $-1.01 \pm 0.17^{\mathrm{b}}$ \\
\hline $50^{\circ} \mathrm{C}$ and $4 \mathrm{~cm} / \mathrm{s}$ & $-17.46 \pm 4.70^{\mathrm{b}}$ & $-16.24 \pm 4.59^{\mathrm{b}}$ & $-1.23 \pm 0.68^{\mathrm{b}}$ \\
\hline
\end{tabular}

a-b Means within the same column with different letters are significantly different $(p \leq 0.05)$.

Although some studies have showed that the osmotic solution temperature increases the rate of solid gain (LOMBARD et al., 2008; EREN and ERTEKIN, 2007), in this work there was loss of solids to all processes, especially for those at $50^{\circ} \mathrm{C}$. This can be ascribed to the high size of the sucralose molecule $(397.60 \mathrm{~g} / \mathrm{mol})$ whose uptake by the yacon tissue is lower than the loss of soluble solids to the solution. 
Figure 2 indicates the effect of the osmotic dehydration on the color and luminosity of yacon, which is desirable in most of the process conditions. In comparison to the in natura slices, luminosity is higher in the samples treated at $30^{\circ} \mathrm{C}$, with or without stirring. Samples treated at $50^{\circ} \mathrm{C}$ presented enzymatic browning and shrinkage. Besides the enzymatic browning, some slices treated at $50^{\circ} \mathrm{C}$ and $4 \mathrm{~cm} / \mathrm{s}$ presented fissures, which may be a result of the combination of heat and stirring, i.e., the impact between the slices and between the slices and the beaker led to structural damages and to a darker tone of yacon. When fissures were opened in the cellular tissue, the enzyme polyphenoloxidase may have been exposed to the yacon surface, suffering the effects of temperature and leading to higher enzymatic browning rates. Besides the fact that the polyphenoloxidase activity is directly dependent on temperature, temperature increases the carbon content of the melanoidins formed by the enzymatic reaction, intensifying its pigmentation (MARTINS, JONGERN \& VAN BOEKEL, 2000).

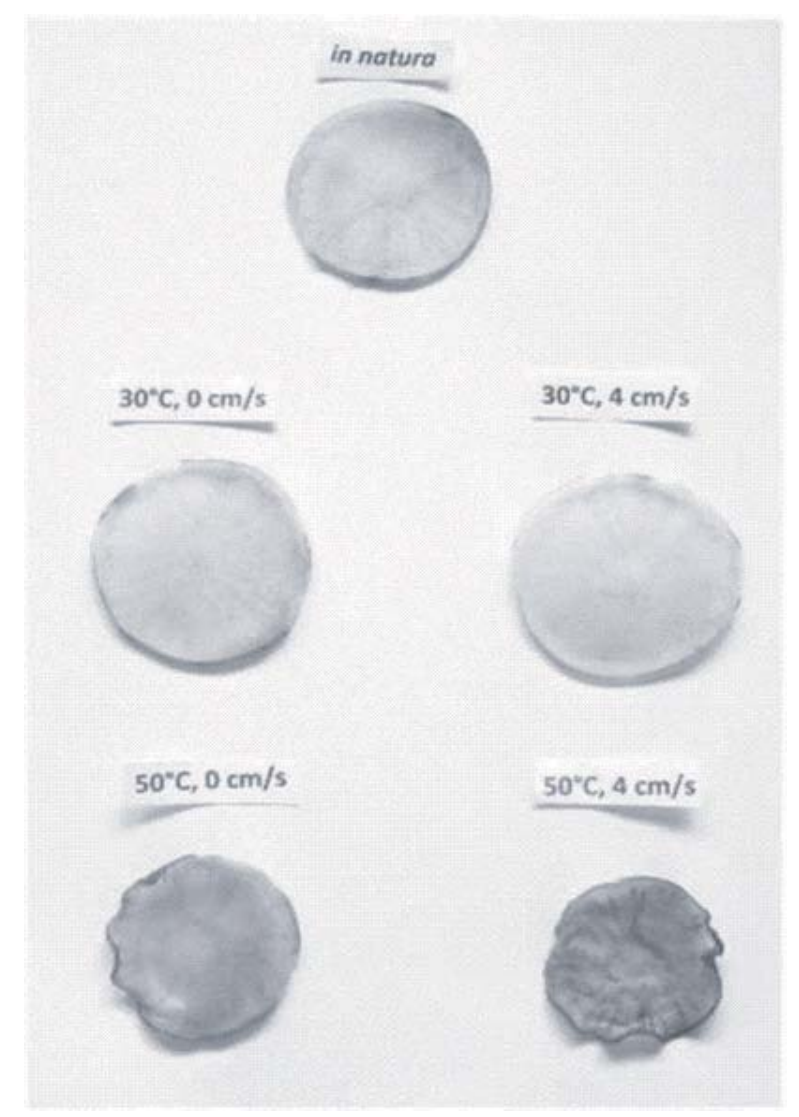

FIGURE 2 - SLICES OF YACON BEFORE AND AFTER THE OSMOTIC TREATMENT

\subsection{CONVECTIVE DRYING}

Figure 3 presents the mass variation of the yacon slices during the convective drying. Drying temperature exercised a positive influence on the process velocity, as expected. In addition, after 2 hours of convective drying, some samples submitted to $80^{\circ} \mathrm{C}$ already achieved the equilibrium moisture content (around $2.5 \%$ w.b.), while yacon dried at $60^{\circ} \mathrm{C}$ continued to lose weight until 3 hours of drying. 


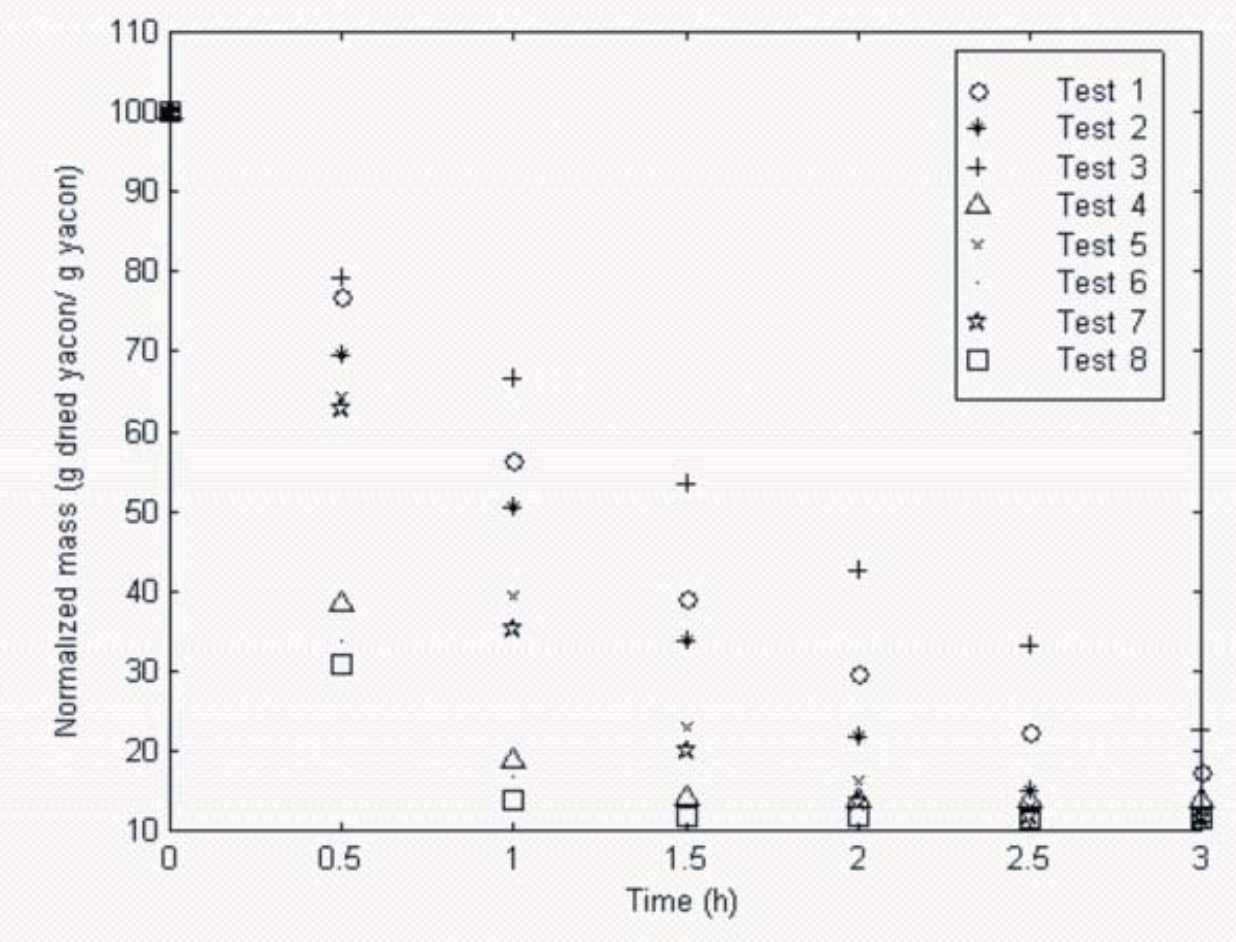

\section{FIGURE 3 - MASS VARIATION OF THE YACON SLICES DURING THE CONVECTIVE DRYING}

Figure 4 shows that the dried yacon slices submitted to the pre-osmotic treatment (Figure $4 b)$ presented a lighter color and less structural damages (shrinkage, angular distortions and fissures) than the samples dried only in the convective drying (Figure 4a), validating the hypothesis sustained by this work. Analyzing the two samples shown in this figure, it is not an overstatement to affirm that the sample not submitted to the osmotic treatment would difficultly be accepted for consume.

During thermal processing of fruits and vegetables, several reactions of color take place: pigment degradation - especially of carotenoids and chlorophyll - browning reactions such as Maillard, and condensation of hexoses and amino components (MASKAN, 2001). In this study, the osmotic treatment seems to exert a protector effect on yacon, leading to a lighter product, probably because the osmotic solution decreases the exposure area of the enzyme to the drying air. In addition, the treated samples reached the convective drying process already with a lower darkening degree comparing to the in natura slices, as showed in Figure 2, so the thermal damage was lower.

During an osmotic treatment, fruits and vegetables often suffer a type of cooking inside the solution, softening the cellular tissues. Moreover, while in the convective drying water loss occurs mainly by diffusional mechanisms, other transport pathways for mass transfer also take place during the osmotic treatment, such as capillary movement and hydrodynamic mechanism (FERRANDO and SPIESS, 2001; RASTOGI et al., 1997). According to Derossi et al. (2008), the hydrodynamic mechanism is related with mechanical relaxation of the cell membranes, decreasing the tensions caused by temperature. This manner, both cooking and tissue relaxation caused by the hydrodynamic transport may have led to the lower levels of shrinkage and angular distortions on dried yacon which received the osmotic treatment. 


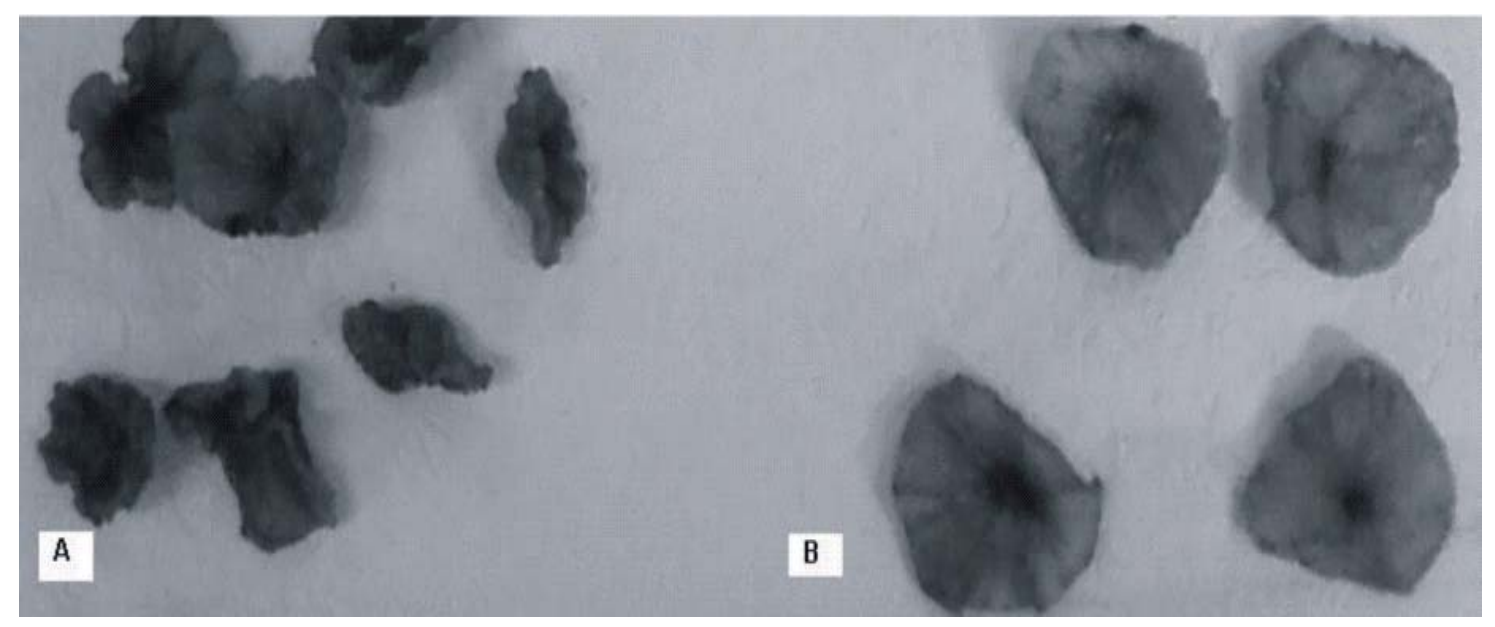

\section{FIGURE 4 - YACON SLICES AFTER THE CONVECTIVE DRYING (A) WITHOUT THE OSMOTIC TREATMENT AND (B) WITH THE OSMOTIC TREATMENT}

There are further explanations for the reduction of defects when the product is submitted to the osmotic treatment. As the drying advances and the water is removed, the interparticle separation decreases, what is manifested as contraction. Thus, the lower the initial moisture content of the product that will undergo drying - which is achieved with the osmotic dehydration - the lower the degree of contraction experienced. Another explanation is that the defects that result from stress caused by temperature, such as angular distortions and rupture, are established from the nonuniform contraction, and osmotic dehydration, homogenizing the concentration of water in yacon, and that leads to more uniform contractions.

\subsection{QUALITY PARAMETERS FOR THE DRIED SAMPLES}

Table 4 presents the answers $y 1$ to $y 4$ obtained in the yacon samples submitted to the osmoconvective drying, where $y 1$ is the moisture content wet basis (\%), y2 is the darkening degree $-\Delta L^{*}$ (dimensionless), $y 3$ is the color change (rad) and y4 is the soluble solids concentration ( ${ }^{\circ} \mathrm{Brix}$ ) of the dried slices. According to the results of Tukey's test, there is a significant difference between different process conditions only for the moisture content $(y 1)$. More specifically, the yacon submitted to $80^{\circ} \mathrm{C}$ in the convective drying offered the driest product, mainly when treated in the osmotic solution using $50^{\circ} \mathrm{C}$, which is the temperature condition that led to higher rates of water and solids loss during the osmotic dehydration.

Analyzing the results obtained in Table 4, it can be noted that the values of moisture content decreased when the solution temperature was raised from $30^{\circ} \mathrm{C}$ to $50^{\circ} \mathrm{C}$, which was expected, since the cellular tissue softening due to the heat action leads to water loss.

Regarding the color alteration, darkening degree and soluble solids concentration, all the samples presented similar results according to the statistical test. Despite of the increasing of mass transfer rate caused by the rising of the solution temperature and stiring rate, the soluble solids concentrations remained similar in all experimental conditions, as shown in Table 4. The variations of color and darkening degree for the osmo treated samples, showed in Figure 2, were annulled during the convective drying. A similar result was observed by Pattanapa et al. (2010). This result, however, does not invalidate the gains attributed to the osmotic treatment, since a great difference of structural integrity between treated samples and just convective dried ones can be easily noted in Figure 4. 


\section{TABLE 4 - EXPERIMENTAL RESULTS OF THE MOISTURE CONTENT WET BASIS (Y1), DARKENING DEGREE (Y2), COLOR CHANGE (Y3) AND SOLUBLE SOLIDS CONCENTRATION (Y4) OF THE DRIED YACON SLICES}

\begin{tabular}{cc|c|cc}
\hline Experimental condition & y1 (\%) & y2 & $y 3(\mathrm{rad})$ & $\boldsymbol{y} 4$ ('Brix) \\
\hline $30^{\circ} \mathrm{C}, 0 \mathrm{~cm} / \mathrm{s}, 60^{\circ} \mathrm{C}$ & $43.20 \pm 8.77^{\mathrm{a}}$ & $-17.40 \pm 0.77^{\mathrm{a}}$ & $1.09 \pm 0.06^{\mathrm{a}}$ & $11.45 \pm 1.35^{\mathrm{a}}$ \\
\hline $50^{\circ} \mathrm{C}, 0 \mathrm{~cm} / \mathrm{s}, 60^{\circ} \mathrm{C}$ & $15.68 \pm 4.52^{\mathrm{bc}}$ & $-17.98 \pm 6.57^{\mathrm{a}}$ & $0.99 \pm 0.41^{\mathrm{a}}$ & $12.05 \pm 1.61^{\mathrm{a}}$ \\
\hline $30^{\circ} \mathrm{C}, 4 \mathrm{~cm} / \mathrm{s}, 60^{\circ} \mathrm{C}$ & $50.45 \pm 4.18^{\mathrm{a}}$ & $-8.44 \pm 1.31^{\mathrm{a}}$ & $1.16 \pm 0.11^{\mathrm{a}}$ & $10.81 \pm 0.97^{\mathrm{a}}$ \\
\hline $50^{\circ} \mathrm{C}, 4 \mathrm{~cm} / \mathrm{s}, 60^{\circ} \mathrm{C}$ & $4.34 \pm 0.70^{\mathrm{bc}}$ & $-16.03 \pm 2.35^{\mathrm{a}}$ & $1.02 \pm 0.34^{\mathrm{a}}$ & $13.98 \pm 0.84^{\mathrm{a}}$ \\
\hline $30^{\circ} \mathrm{C}, 0 \mathrm{~cm} / \mathrm{s}, 80^{\circ} \mathrm{C}$ & $5.23 \pm 0.66^{\mathrm{b}}$ & $-7.30 \pm 2.93^{\mathrm{a}}$ & $1.16 \pm 0.08^{\mathrm{a}}$ & $10.69 \pm 0.59^{\mathrm{a}}$ \\
\hline $50^{\circ} \mathrm{C}, 0 \mathrm{~cm} / \mathrm{s}, 80^{\circ} \mathrm{C}$ & $2.94 \pm 0.80^{\circ}$ & $-9.92 \pm 6.86^{\mathrm{a}}$ & $1.26 \pm 0.18^{\mathrm{a}}$ & $11.83 \pm 1.77^{\mathrm{a}}$ \\
\hline $30^{\circ} \mathrm{C}, 4 \mathrm{~cm} / \mathrm{s}, 80^{\circ} \mathrm{C}$ & $5.87 \pm 1.60^{\circ}$ & $-8.76 \pm 0.62^{\mathrm{a}}$ & $1.16 \pm 0.14^{\mathrm{a}}$ & $10.59 \pm 0.66^{\mathrm{a}}$ \\
\hline $50^{\circ} \mathrm{C}, 4 \mathrm{~cm} / \mathrm{s}, 80^{\circ} \mathrm{C}$ & $3.17 \pm 0.08^{\mathrm{c}}$ & $-15.54 \pm 0.01^{\mathrm{a}}$ & $1.13 \pm 0.13^{\mathrm{a}}$ & $12.24 \pm 4.47^{\mathrm{a}}$ \\
\hline
\end{tabular}

${ }^{a-c}$ Means within the same column with different letters are significantly different $(p \leq 0.05)$.

Above all, the results presented in Table 4 reveal that it is possible to obtain dried yacon slices with different moisture contents but with no significant changes in color, darkening degree and soluble solids content.

\section{CONCLUSION}

The present study evaluated the osmo-convective drying of yacon on its centesimal composition and quality attributes, as darkening degree, color change and soluble solids concentration.

The results showed a little alteration in the centesimal composition of yacon due to the osmotic treatment. The carbohydrates and water contents were mainly affected by the osmotic dehydration, as expected. The losses of minerals and proteins were slightly changed and the fat content remained the same. These results indicate that the osmotic treatment did not damage the nutritional value of yacon. It could be also verified that the solution temperature played a fundamental role in the osmotic dehydration process, towards water and solids transfers. The yacon slices obtained using the osmo-convective drying presented higher luminosity and less structural damages related to fissures, shrinkage and angular distortions compared to just convective dried yacon.

In relation to the osmo-convective dried samples in different conditions, it could be verified that the moisture content significantly changed, meaning that the temperatures and stirring rates used in this work can be combined in order to achieve the desired final moisture. The results also indicated that there was no difference towards darkening degree, color change and soluble solids concentration in the samples obtained in different experimental conditions. 


\section{RESUMO}

\section{AVALIAÇÃO DA DESIDRATAÇÃO OSMO-CONVECTIVA NOS ATRIBUTOS DE QUALIDADE E COMPOSIÇÃO CENTESIMAL DO YACON (Smallanthus sonchifolius)}

Investigou-se a aplicação da desidratação osmo-convectiva em raízes de yacon, com relação à sua composição centesimal e atributos de qualidade. Fatias de yacon foram submetidas ao tratamento osmótico em solução de sucralose e depois à secagem convectiva. Os experimentos seguiram planejamento fatorial completo $\left(2^{3}\right)$ para avaliar a influência de três variáveis de processo (temperatura e taxa de agitação da solução osmótica e temperatura de secagem) em quatro atributos de qualidade (conteúdo de umidade, cor, luminosidade e conteúdo de sólidos solúveis). As fatias de yacon osmo-desidratadas apresentaram desejável conteúdo de umidade, baixos níveis de mudança de cor e escurecimento e menores danos estruturais em comparação com o produto seco diretamente em estufa. Os efeitos do tratamento osmótico na composição centesimal do yacon mostraram principalmente a absorção de sucralose e perda de água, sem prejuízo significativo dos seus atributos nutricionais. O produto obtido apresentou diferentes conteúdos de umidade, mas similares graus de escurecimento e mudanças de cor em diferentes condições experimentais.

PALAVRAS-CHAVE: YACON; SECAGEM CONVECTIVA; TRATAMENTO OSMÓTICO; GRAU DE ESCURECIMENTO; DANOS ESTRUTURAIS; COMPOSIÇÃO CENTESIMAL.

\section{REFERENCES}

1 ANTONIO, G.C.; AZOUBEL, P.M.; MURR, F.E.; PARK, K.J. Osmotic dehydration of sweet potato (Ipomoea batatas) in ternary solutions. Ciência e Tecnologia de Alimentos, v. 28, p. 696-701, 2008.

2 ARAÚJO, L.C. Otimização da desidratação osmótica do jambo-vermelho (Syzygium malaccens). 2009. 93 f. Dissertação (Mestrado em Ciência e Tecnologia de Alimentos), Universidade Federal de Pernambuco, Recife, 2009

3 CHUA, K.J.; MUJUMDAR, A.S.; HAWLADER, M.N.A.; CHOU, S.K.; HO, J.C. Batch drying of banana pieces-effect of stepwise change in drying air temperature on drying kinetics and product colour. Food Research International, v. 34, p. $721-731,2001$

4 DEROSSI, A.; DE PILLI, T.; SEVERINI, C.; MCCARTHY, M. Mass transfer during osmotic dehydration of apples. Journal of Food Engineering, v. 86, p. 519-528, 2008.

5 EREN, I,; KAYMAK-ERTEKIN, F. Optimization of osmotic dehydration of potato using response surface methodology. Journal of Food Engineering, v. 79, p. 344-352, 2007.

6 FERRANDO, M.; SPIESS, W.E.L. Cellular response of plant tissue during the osmotic treatment with sucrose, maltose, and trehalose solutions. Journal of Food Engineering, v. 49, p. 115-127, 2001.

7 HARTEMINK, R.; VANLAERE, K.M.J.; ROMBOUTS, F.M. Growth of enterobacteria on fructo-oligosaccharides. Journal of Applied Microbiology, v. 383, p. 367-374, 1997.

8 HERMANN, M.; FREIRE, I. Compositional diversity of the yacon storage root. Lima: Centro Internacional de la Papa, 1998

9 IBITWAR, B.B.; KAUR, B.; ARORA, S.; PATHARE, P.B. Osmo-convective dehydration of plum (Prunussalicina L). International Journal of Food Engineering, v. 4, p. 132-141, 2008.

10 INSTITUTO ADOLFO LUTZ. Normas analíticas do Instituto Adolto Lutz: métodos químicos e físicos para análises de alimentos. 3. ed. São Paulo: 1985. v.1.

11 ISPIR, A.; TOGRUL, I.C. Osmotic dehydration of apricot: kinetics and the effect of process parameters. Chemical Engineering Research and Design, v. 87, p. 166-180, 2009

12 JENNER, M.R.; SMITHSON, A. Physicochemical properties of the sweetener sucralose. Journal of Food Science, v. 54, p. 1646-1649, 1989.

13 KEPPEL, G.; WICKENS, T.D. Design and analysis: a researcher's handbook. $4^{\text {th }}$ ed. New York: Prentice Hall, 2004.

14 LAZARIDES, H.N.; KATSANIDIS, E.; NICKOLAIDIS, A. Mass transfer kinetics during osmotic preconcentration aiming at minimal solid uptake. Journal of Food Engineering, v. 25, p. 151-166, 1995. 
15 LAWLESS, H.T.; HEYMANN, H. Sensory evaluation of food: principles and practices. $2^{\text {nd }}$ ed. New York: Springer, 2010.

16 LENART, A. Osmo-convective drying of fruits and vegetables: technology and application. Drying Technology, v. 14, p. $391-413,1996$

17 LOMBARD, G.E.; OLIVEIRA, J.C.; FITO, P.; ANDRÉS, A. Osmotic dehydration of pineapple as a pretreatment for further drying. Journal of FoodEngineering, v. 85, p. 277-284, 2008.

18 MALDONADO, S.; SANTAPAOLA, J.E.; SINGH, J.;TORREZ, M.; GARAY A. Cinética de la transferencia de masa durante la deshidratación osmótica de yacón (Smallanthus sonchifolius). Ciência e Tecnologia de Alimentos, v. 28, p. 251-256, 2008.

19 MARTINS, S.I.F.S.; JONGERN, W.M.F.; VANBOEKEL, M.A.J.S.. A review of Maillard reaction in food and implications to kinetic modeling. Trends in Food Science and Technology, v. 11, p. 364-373, 2000.

20 MASKAN, M. Kinetics of colour change of kiwifruits during hot air and microwave drying. Journal of Food Engineering, v. 48, p. $169-175,2001$.

21 MASSON, M.L.; MOURA, C.P.; YAMAMOTO, C. Osmo-convective effect on the color of yacon (Polymnia sonchifolia). In: INTERNATIONAL DRYING SYMPOSIUM, 14., São Paulo. Proceedings ... São Paulo: UNICAMP, 2004. v. C, p. 17071711.

22 MATISSEK, R.; SCHNEPEL, F.M.; STEINER, G. Análisis de los alimentos: fundamentos, métodos, aplicaciones. Zaragoza: Acribia, 1998.

23 MUNDADA, M.; SINGH, B.; MASKE, S. Optimization of processing variables affecting the osmotic dehydration of pomegranate arils. International Journal of Food Science and Technology, v. 45, p. 1732-1738, 2010.

24 NACHTIGALL, A.M.; ZAMBIAZI, R.C. Geléias de hibisco com reduzido valor calórico: características sensoriais. Boletim do CEPPA, v. 24, n. 1, p. 47-58, 2006.

25 OZDEMIR, M.; OZEN, B.F.; DOCK, L.L.; FLOROS, J.D. Optimization of the osmotic dehydration of diced green peppers by response surface methodology. LWT -Food Science and Technology, v. 41, p. 2044-2050, 2008.

26 PATTANAPA, K.; THERDTHAI, N.; CHANTRAPORNCHAI, W.; ZHOU, W. Effect of sucrose and glycerol mixtures in the osmotic solution on characteristics of osmotic dehydrated mandarin $\mathrm{cm}$ (Sai-Namphaung). International Journal of Food Science and Technology, v. 45, p. 1918-1924, 2010.

27 PEDRESCHI, R.; CAMPOS, D.; NORATTO, G.; CHIRINOS, R.; CISNEROS-ZEVALLOS, L. Andean yacon root (Smallanthus sonchifolius Poepp. Endl) fructooligosaccharides as a potential novel source of prebiotics. Journal of Agricultural and Food Chemistry, v. 51, p. 5278-5284, 2003.

28 PEKOSLAWSKA, A.; LENART, A. Osmotic dehydration of pumpkin in starch syrup. Journal of Fruit and Ornamental Plant Research, v. 17, p. 107-113, 2009.

29 RAOULT-WACK, A.L.; RIOS, G.; SUREL, R.; GIROUX, F.; GUILBERT, S. Modelling of dewatering and impregnation soaking process (osmotic dehydration). Food Research International, v. 27, p. 207-209, 1994

30 RASTOGI, N.K.; RAGHAVARAO, K.S.M.S.; NIRANJAN, K.; KNORR, D. Mass transfer during osmotic dehydration of banana: Fickian diffusion in cylindrical configuration. Journal of Food Engineering, v. 31, p. 423-432, 1997.

31 SINGH, B.; KUMAR, A.; GUPTA, A.K. Study of mass transfer kinetics and effective diffusivity during osmotic dehydration of carrot cubes. Journal of Food Engineering, v. 79, p. 471-480, 2007.

32 TAKENAKA, M.; YAN, X.; ONO, H.; YOSHIDA, M.; NAGATA, T.; NAKANISHI, T. Caffeic acid derivatives in the roots of yacon (Smallanthus sonchifolius). Journal of Agricultural and Food Chemistry, v. 51, p. 793-796, 2003.

33 TORREGGIANI, D. Osmotic dehydration in fruit and vegetable processing. Food Research International, v. 26, p. 59-69, 1993.

34 VEGA-GÁLVEZ, A.; MIRANDA, M.; CLAVERÍA, R.; QUISPE, I.; VERGARA, J.; URIBE, E.; PAEZ, H.; DI SCALA, K. Effect of air temperature on drying kinetics and quality characteristics of osmo-treated jumbo squid (Dosidicus gigas). LWT Food Science and Technology, v. 44, p. 16-23, 2011.

35 VIEIRA, G.S.; PEREIRA, L.M.; HUBINGER, M.D. Optimization of osmotic dehydration process of guavas by response surface technology and desirability function. International Journal of Food Science and Technology, v. 47, p.132-147, 2012

36 YAN, $\mathrm{X}$; SUZUKI, M.; OHNISHI-KAMEYAMA, M.; SADA, Y.; NAKANISHI, T.; NAGATA, T. Extraction and identification of antioxidants in the roots of yacon (Smallanthus sonchifolius). Journal of Agricultural and Food Chemistry, v. 47, p. 4711-4713, 1999 


\section{ACKNOWLEDGEMENTS}

The authors would like to thank CAPES (Brazil) for the scholarship granted to the first author. This study was partially supported by the National Council of Scientific and Technologic Development of Brazil (CNPq) under Grants 302786/2008-2/PQ, 568221/2008-7 and 475689/2010-0. 